\title{
ПРОБЛЕМА ПРИНЦИПУ СПРАВЕДЛИВОСТІ У ДОГОВІРНИХ ЗОБОВ'ЯЗАННЯХ
}

\author{
ГАЛУШКО Вікторія Анатолї̈вна - студент за ОР «Магістр» юридичного \\ факультету Київського національного університету імені Тараса Шевченка
}

DOI:10.32782/NP.2020.1.25

УДК: 347.44

Статья посвящена анализу проблемь неоднозначного толкования приниипа справедливости в договорном праве. Бъили исследованъ доктринальнъие подходъ к определению справедливости, а также разграниченъ толкования категории справедливости в билособии и в праве. В работе освещаются случаи применения принципа справедливости в судебной практике и в договорнъих обязательствах.

Ключевъие слова: приниипь, поведение участников гражданских отношений, оббективное право, беспристрастность, равенство участников договорнъхх обязательств.

\section{Постановка проблеми}

У зв'язку з можливістю використовувати аналогію права, яку закріпила ч. 2 ст. 8 Цивільного кодексу України, цивільні відносини можуть регулюватися відповідно до загальних засад цивільного законодавства, серед яких важливе місце посідає недостатньо досліджений принцип справедливості.

Аналіз останніх досліджень і публікацій

Окрім законодавчого закріплення на національному рівні та наявності тлумачення принципу справедливості у міжнародноправових актах, дана тематика досліджувалась досить великою кількістю як учених-цивілістів, так і філософів, політологів(А.Ю. Аракелян, І.Г. Бабич, С. М. Бервено, Т.В. Боднар, А.А. Демінська, С.А. Іванова, О.О. Отраднова, С.О. Погрібний, О.А. Потапова, Ю.А. Тобота, Р.А. Майданик, Ю.В. Цю- кало, O.I. Мацегорін та інші). Незважаючи на те, що сьогодні принцип справедливості багато досліджується та описується, він так і не отримав єдиного підходу до його розуміння.

\section{Формулювання цілей}

Завданням статті є встановлення місця принципу справедливості у договірних зобов'язаннях через окреслення його характерних рис та випадків практичного застосування.

\section{Виклад основного матеріалу}

Головні властивості та особливості будьякого права виражаються за допомогою певних принципів. Принципи, чи інакше, основоположні ідеї формують та виражають зв'язок між сущим та належним. У результаті європейської інтеграції та світової глобалізації в Україні закріпилися нові концептуальні підходи, завдяки яким цивільне право загалом та договірне право зокрема наповнилися конкретними моральними засадами: справедливості, добросовісності та розумності. Цивільний кодекс України (далі - ЦК України) зазначив дані засади у ст. 3 [1].

ЦК України неодноразово вживає у своїй термінології оціночні поняття й категорії. До таких відносять і вищезазначені категорії справедливості, добросовісності та розумності. Вони $є$ окремими, але взаємопов'язаними гранями поведінки учасників цивільних правовідносин. Аналі- 


\section{Цивільне, підприємницьке, господарське та трудове право}

зуючи дані правові феномени, А.Дж. Барнард говорить про моральні елементи договору, досліджуючи дані категорії не тільки 3 правових, а й з етичних позицій.

Першочергово, філософська категорія справедливості виникла в результаті формування уявлень людей про поняття добра i зла. Під справедливими вчинками розуміли такі діяння, які відповідали моральним устоям та моральним уявленням всього соціуму або більшої його частини. Багато філософів та політичних діячів присвячували свої праці темі справедливості, і згодом дана категорія знайшла своє відображення в законодавчих текстах. На ранніх стадіях формування держави звичаї, як зовнішній прояв уявлень про справедливість, були основними джерелами формування права [6]. Саме через це існують теоретичні положення та думки, які ототожнюють, плутають поняття закону та справедливості.

Проте, справедливість аж ніяк не створено законом: навпаки, закон завжди є лише тлумаченням і втіленням справедливості. Такий вислів належить французькому соціалісту П'єру Жозефу Прудону. Йому був притаманний ідеалізм, який ми можемо спостерігати і в наведеній цитаті. Проте, 3 цим висловом важко не погодитись. Дійсно, навіть закон деколи буває несправедливим, адже ми не можемо оминути об'єктивну дійсність - низьку правову освіту деяких законотворців, корупцію та інші негативні чинники, які впливають на прийняття нормативно-правових актів в країні.

Арістотель, зокрема, поділяв справедливість на два види - природну і встановлену законом. Справедливість від природи - це та, що залишається в більшості випадків такою. Те, що ми самі визнаємо справедливим, стає після цього таким, ми і називаємо його справедливим за законом [1].

Нині у правовій та філософській літературі існує декілька позицій щодо розуміння справедливості. Одні автори вважають, що справедливість - це об'єктивне явище, зріз суспільних відносин. Друга група вчених стверджує, що справедливість є суб'єктивним явищем та водночас - морально-етична категорія, що відображається у відповідній морально-етичній формі.
Прихильники третьої групи вважають, що справедливість одночасно поєднує в собі об'єктивне і суб'єктивне [4]. Останній підхід найбільш широко, на думку багатьох учених, розкриває сутність категорії «справедливість». Проте необхідно визначити, про яке «об'єктивне» та «суб'єктивне» ведеться мова. У літературі існує поняття об'єктивного та суб'єктивного права, проте в наведених підходах до розуміння категорії справедливості вчені використовують термін «об'єктивне явище», що є не правовим, а філософським поняттям. У той час як об'єктивне право являє собою систему всіх чинних у країні норм права, відбитих в різних джерелах і не залежних від індивіда [11], об'єктивне явище чи об'єктивна дійсність у філософському розумінні представляє собою характеристику предмета, зміст знання чи спосіб існування, яка полягає в їхній незалежності від людської свідомості (суб'єкта пізнання) [12].

Виходячи з вищезазначеного можна зробити наступний висновок. Категорія справедливості, безперечно, застосовується як в об'єктивному, так і суб'єктивному праві.Ïї зміст зумовлюється різними чинниками: насамперед, це часові та територіальні фактори. Те, що вважається справедливим в один часовий проміжок, може вважатися вкрай несправедливим за інші часи. 3 цієї точки зору справедливість постає перед нами як динамічна категорія. У такому разі, чи доречно говорити про категорію справедливості як таку, що існує в об'єктивній дійсності, яка не залежить від людини? Адже динаміка розвитку розуміння категорії справедливості зумовлена зміною саме в суспільній сфері - там, де панує людина. Саме тому вплив людського фактору (розвитку суспільства) на зміну визначення категорії справедливості унеможливлюе ії приписання до об'єктивного явища, тобто такого, що існує незалежно від людської свідомості. Така позиція не суперечить думці П'єра Жозефа Прудона чи Арістотеля, оскільки дані автори заперечували існування справедливості тільки 3 прив'язкою до закону, а говорили про право (що в широкому розумінні - це не тільки законодавство). Принцип справедливості є принципом права. Якщо розглядати принцип справедливості як принцип зако- 
нодавства, то тут він співпадає з принципом законності, а природне право існує, навіть не знаходячи своє регулювання у нормативно-правових актах.

Саме тому, розглядаючи категорію справедливості у вузькій сфері - у договірних зобов'язаннях, мається на увазі справедливість 3 точки зору об'єктивного та суб'єктивного права, оминаючи положення філософії (моралі тощо), роблячи акцент на соціально-правових підходах, визначених як національним законодавством та напрацюваннями вчених-цивілістів, так і міжнародними актами.

Поняття «справедливість» охоплюе відповідність поведінки суб'єктів зобов'язальних відносин панівним у суспільстві моральноетичним нормам, яка сприймається широким загалом і оцінюється як доцільна і правильна [8]. Принцип справедливості можна визначати також як встановлений нормами права обсяг, межі здійснення і захисту цивільних прав та інтересів особи адекватно ії ставленню до вимог правових норм. У правовій літературі зазначається, що в силу абстрактного характеру цього принципу розкрити повністю його зміст досить проблематично, i пропонується включати в нього такі елементи, як: рівність суб’єктів права, свобода договору, необхідність урахування всіх істотних обставин при розгляді конкретної справи судом [9]. Так, на думку Т.В. Боднар, з правового погляду справедливість при здійсненні цивільно-правових зобов'язань визначається як поведінка кожної зі сторони зобов'язання по відношенню до своїх прав і обов'язків, яка б виключала необ'єктивні (неупереджені, несправедливі) дії сторін зобов'язання стосовно одна одної, а $з$ другого - у справедливій (об'єктивній, неупередженій, з урахуванням етичних та інших моральних аспектів) оцінці судом поведінки суб'єктів зобов'язальних правовідносин [2]. Отже, за цивільним законодавством України принцип справедливості, визначаючи межі здійснення суб'єктивних прав, вимагає таких умов поведінки:

1) відповідність поведінки уповноваженої особи до умов договору (якщо він існував) або до актів цивільного законодавства;

2) врахування публічного інтересу і моральних засад суспільства;
3) відсутність зловживання правом.

Слід зазначити, що європейська практика виділяє процедурну (procedural) i матеріальну (substantive) справедливість, при цьому матеріальна несправедливість означає нееквівалентність зустрічних надань, а процедурна - використання нерівних можливостей щодо узгодження умов договору. Більшість західних авторів схиляеться до втручання в договірні умови після встановлення їх процедурної несправедливості [14]. Британські вчені Дж. О'Салліван і Дж. Хілліард вважають, що при розгляді питання справедливості в договірних зобов'язаннях слід більшою мірою звертати увагу на матеріальну ознаку і досліджувати питання про сумлінність у діях сторін, ніж обмежуватися аналізом формальних ознак [15].

Сторони договору, укладаючи договір, сподіваються на його виконання. Відповідно до принципу справедливості зобов'язання має виконуватись із поєднанням принципу належного виконання. Відповідно до цієї конструкції виконання належною стороною, в належному місці, в належний строк, у належний спосіб доповнюється вимогою виконання зобов'язання відповідно до мети договору, що є вимогою принципу справедливості і гарантією захисту прав та інтересів учасників правовідносин.

Наприклад, принцип справедливого розподілу прибутку за договором про спільну діяльність сторони полягає у тому, що при здійсненні такого розподілу сторони мають враховувати комплекс чинників, що мають істотне значення (ст. 1139 ЦК України) [13].

Судова практика свідчить про те, що суди все частіше звертають увагу суб'єктів цивільних відносин на неприпустимість порушення принципу справедливості при здійсненні ними своїх суб'єктивних прав. Підтвердженням цього може слугувати, наприклад, рішення Верховного суду у складі колегії суддів Касаційного цивільного суду від 12.12.2018 р. стосовно несправедливого положення договору про споживчий кредит, зокрема щодо плати за обслуговування кредиту. Підставою для такого рішення стали положення ч. 5 ст. 11, частин $1,2,5$ ст. 18 Закону України «Про захист прав спо- 


\section{Цивільне, підприємницьке, господарське та трудове право}

живачів», відповідно до яких до договорів зі споживачами про надання споживчого кредиту застосовуються положення цього Закону про несправедливі умови в договорах, зокрема положення, згідно з якими передбачаються зміни в будь-яких витратах за договором, крім відсоткової ставки [5]. У рішенні зазначається, що продавець (виконавець, виробник) не повинен включати у договори із споживачем умови, які є несправедливими. Умови договору є несправедливими, якщо всупереч принципу добросовісності його наслідком є істотний дисбаланс договірних прав та обов'язків на шкоду споживача. Якщо положення договору визнано несправедливим, включаючи ціну договору, таке положення може бути змінено або визнано недійсним. Положення, що було визнане недійсним, вважається таким 3 моменту укладення договору. Суд дійшов висновку, що несправедливими є положення договору про споживчий кредит, які містять умови про зміни у витратах, зокрема щодо плати за обслуговування кредиту, і це є підставою для визнання таких положень недійсними [3].

Крім того, метою захисту споживачів від зловживань з боку продавців і постачальників, зокрема у випадку застосування ними підготовлених в односторонньому порядку стандартних договорів, у країнах європейського права нормативно визначаються правила захисту споживачів від несправедливих договорів.

У європейському законодавстві існує поняття «несправедливі умови договору», визначене Директивою 93/13/EC «Про несправедливі умови в споживчих договорах». Згідно $з$ Директивою умова договору, яка не була окремо погоджена, вважається несправедливою (нечесною), якщо на противагу вимоги про добросовісність вона створюе значний дисбаланс у правах і обов'язках сторін договору, причому на шкоду споживачу. Несправедливою умова може бути визнана лише в тому випадку, якщо вона не була окремо погоджена сторонами, причому не внаслідок того, що сторони не бажали цього, а з огляду на те, що споживач з об'єктивних причин не міг виразити свою волю щодо такої умови договору. Головною серед таких причин Директива називає саме наявність заздалегідь підготовленого контрагентом споживача проекту договору, в результаті чого останній був практично позбавлений можливості запропонувати внесення будьяких змін у нього [7].

\section{Висновки}

Отже, сучасне розуміння справедливості обумовлене уявленням про людину, сформовану новою європейською культурою. Це уявлення про людину як про самостійного індивідуума, наділеного невідчужуваними правами та здатного самостійно контролювати та регулювати свою поведінку у суспільстві на підставі певних загальновизнаних норм. Визнання принципу справедливості як основного, системоутворюючого, загального принципу права пов'язане із набуттям природним правом пріоритетної ролі над правом позитивним. Принцип справедливості є гарантією захисту цивільних прав та інтересів суб'єктів цивільного права, він визначає межі здійснення суб'єктивних прав. Дія цього принципу має бути спрямована на досягнення і підтримання справедливого балансу майнових прав і інтересів учасників цивільних правовідносин, коли їхні дії не призводитимуть до несправедливого, нерозумного чи недобросовісного результату.

\section{Мiтература}

1. Аристотель. Сочинения: В 4-х т. Т. 4 / Перевод с древнегреческого; общая редакция А. И. Доватура. М., 1983.

2. Боднар Т.В. Виконання договірних зобов’ язань у цивільному праві: Монографія / Т.В. Боднар. - К.: Юрінком Інтер, 2005.

3. Олександр Б. Несправедливими є положення договору про споживчий кредит, які містять умови про зміни у витратах, зокрема щодо плати за обслуговування кредиту, і це є підставою для визнання таких положень недійсними (ВСКЦС, справа № 444/484/15-ц, 12.12.18) [Електронний ресурс] - Режим доступу: https:/ protocol.ua/ru/vs_ktss_nespravedlivimi_e_ pologennya_dogovoru_pro_spogivchì_ kredit_yaki_mistyat_umovi_pro_zmini_u_ vitratah_zokrema_shchodo_plati_za obslugovuvannya_kreditu_i_tse_e_pidstavoyu_ 


\section{АНОТАЦІЯ}

Статтю присвячено аналізу проблеми неоднозначного трактування приниипу справедливості у договірному праві. Було досліджено доктринальні підходи до визначення справедливості, а також розмежовано тлумачення категорї справедливості у білособюї та у праві. У роботі висвітлюються випадки застосування принициу справедливості у судовій практиці та договірних зобов'язаннях.

Ключові слова: засади, поведінка учасників ициільних відносин, об'єктивне право, неупередженість, рівність учасників договірних зобов'язань.

dlya_viznannya_takih_pologen_nediysnimi_ (vsktss_sprava_444_484_15_ts_12_12_18)/.

4. Деревесников А.В. Справедливость как принцип права (историко-теоретический аспект): дисс. ... канд. юрид. наук: 12.00.01 / А.В. Деревесников. - Кострома, 2005. - 155 c.

5. Закон України «Про захист прав споживачів» [Електронний ресурс]. - 1991. - Режим доступу: https://zakon.rada.gov.ua/ laws/show/1023-12.

6. Майданик Р.А. Проблеми довірчих відносин в цивільному праві. К., 2002.

7. Майданик Р. А. Цивільне право. Загальна частина. Том 1. Вступ в цивільне право. Навчальний посібник / Р. А. Майданик., 2012.

8. Мацегорін О. I. Аксіологія принципів зобов'язального права // Проблеми цивільного та підприємницького права в Україні / 2011.

\section{SUMMARY}

The article is devoted to the analysis of the problem of ambiguous interpretation of the principle of justice in contract law. Doctrinal approaches to the definition of justice were explored, as well as interpretations of the category of justice in philosophy and in law were delimited. The work covers cases of the application of the principle of justice in case law and contractual obligations.

Keywords: principles, behavior of participants of civil-law relations, objective law, impartiality, equality of parties to contractual obligations.

9. Мережко A.A. Lex mercatoria: теория и принципы транснационального торгового права / А.А. Мережко. - К.: Таксон, 1999.

10. Науково-практичний коментар до Цивільного кодексу України. [Електронний pecypc]. - Режим доступу: http://radnuk.info/ komentar/chky.html

11. Крестовська Н.М., Матвеева А.Г. Теорія держави і права: Елементарний курс. Видання друге. - Х.: ТОВ «Одіссей», 2008.

12. Свириденко В. Об'єктивність // Філософський енциклопедичний словник /B. I. Шинкарук (голова редколегії) та ін. ; А. В. Озадовська, Н. П. Поліщук (наукові редактори) ; І. О. Покаржевська (художне оформлення). - Київ : Абрис, 2002.

13. Цивільний кодекс України [Електронний ресурс]. - 2003. - Режим доступу: https://zakon.rada.gov.ua/laws/show/435-15. 333.

14. Zweigert K., Kotz H. Op. cit. P. 330-

15. O'Sullivan J., Hilliard J. The Law of Contract. - Oxford, 2010. P. 216-218. 